\title{
Bráðir kviðverkir af völdum slitróttrar bráoaporfýríu - sjúkratilfelli og yfirlit
}

\begin{abstract}
Brynhildur Tinna Birgisdóttir $^{1}$ læknir

Hilmir Ásgeirsson ${ }^{1}$ læknir

\section{Steinunn Arnardóttir ${ }^{1}$}

Lýst er bráđu porfýríukasti hjá konu sem hafði leitað endurtekið á bráðamóttöku vegna kviðverkja. Porfýríur orsakast af skertri ensímvirkni í myndunarferli hems og við ákveðið álag verður uppsöfnun á milliefnum í ferlinu vegna pessa. Einkenni geta verið kviðverkir, ógleði og uppköst, hægðabreytingar, hraður hjartsláttur og blóðprýstingshækkun. Meðferðin felst í að fjarlægja mögulega orsakavalda, meðhöndla einkenni og gefa kolvetni eða hemín til að draga úr myndun milliefna.
\end{abstract} læknir

Jón Jóhannes Jónsson ${ }^{2,3}$ meinefnafræðingur

\section{Brynjar \\ Viðarsson ${ }^{1,4,5}$ \\ blóðlæknir}

Lykilorð: slitrótt bráđaporfýría, meingerð, faraldsfræði, meðferð.



\section{Ágrip}

\section{Sjúkratilfelli}

Miðaldra kona frá Austur-Evrópu leitaði á bráðamóttöku eftir að hafa verið með vaxandi kviðverki um neðanverðan kvið með leiðni aftur í bak ásamt slappleika, ógleði og lystarleysi í fjóra daga. Hún hafði nánast ekkert getað nærst síðustu dagana fyrir komu. Petta var í priðja skipti á premur dögum sem konan leitaði á bráđamóttöku vegna svipaðra einkenna sem pá höfðu svarað verkjalyfjum. Líkamsskoðun og niðurstöður blóðrannsókna á peim tíma voru ósértækar fyrir utan að grunur vaknaði um pvagfærasýkingu sem var meðhöndluð með mecillínami. Konan hafði áður haft háprýsting og vanstarfsemi á skjaldkirtli en annars verið hraust.

Skoðun leiddi í ljós að konan var meðtekin og slöpp. Hún var hitalaus, blóðprýstingur var 174/105, púls 67 slög á mínútu og súrefnismettun 96\% án súrefnis. Slímhúð í munni var purr. Nokkur eymsli voru við preifingu um neðanverðan kvið en ekki sleppieymsli. Kviður var mjúkur og garnahljóð eðlileg. Niðurstöður blóðrannsókna má sjá í töflu I. Ketónar voru í pvagi en annars var almenn pvagrannsókn ómarkverð. Yfirlitsmynd og síðan tölvusneiðmynd af kvið sýndu talsvert magainnihald og mikið loft í ristli en ekki annað óeðlilegt.

Eftir töf vegna tungumálaerfiðleika kom í ljós að konan hafði verið greind með porfýríu fyrir um 20 árum í heimalandi sínu. Hún hafði pá verið með slappleika og kviðverki líkt og nú en verið einkennalaus síðan. Undanfarnar vikur hafði hún breytt yfir í svokallað blóðflokkamataræði sem var jafnframt mjög kolvetnasnautt. Ásamt pessu hafði hún notað stólpípur reglulega, síðast fjórum dögum fyrir komu. Vegna gruns um porfýríukast var hún lögð inn og hafin meðferð með $5 \%$ glúkósulausn í dreypi.

Við nánari pvagskoðun daginn eftir var pvag rauðbrúnleitt og jákvætt fyrir porfóbilinógeni (1+) og úró-/kópróporfýríni (3+) með eigindlegum útdráttarrannsóknum. Skipt var yfir í $10 \%$ glúkósalausn í æð ásamt næringu í æð (sambland af glúkósalausn, amínósýrulausn og fitufleyti, Structokabiven ${ }^{\circledR}$ ) og orkudrykkjum (langkeðjupríglýseríðar, Calogen ${ }^{\circledR}$ ). Markmiðið var að hún fengi 300-400 grömm af kolvetnum á sólarhring en vegna ógleði og lystarleysis gat hún nær ekkert nærst um munn. Notast var við parasetamól og morfín til verkjastillingar og prómetazín (Phenergan ${ }^{\circledR}$ ) við ógleði. Blóðprýstingur var hár fyrstu tvo sólarhringana og fór slagbilsprýstingur í 185-200 mmHg en lækkaði eftir gjöf labetalóls. Á priðja degi innlagnar féll natríumgildi í plasma (tafla I) en á sama tíma var natríumgildi í pvagi hátt, $133 \mathrm{mmól} / \mathrm{l}$, og osmólalítet pvags eðlilegt, $480 \mathrm{mosm} / \mathrm{kg}$ (300900). Hún var pá purr að sjá og við mælingu réttstöðuprýstings féll hann úr 159/88 í 112/76 mmHg og púls jókst úr 69 í 85 slög á mínútu. Pví var gefið ríkulega af saltvatni í æð en jafnframt haldið áfram að gefa $10 \%$ glúkósulausn til kolvetnagjafar. Lípasi í blóði hækkaði á priðja degi en varð svo aftur eðlilegur (tafla I). Ómskoðun af lifur, gallvegum, brisi og nýrum sýndi væga fitulifur en var annars ómarkverð. Sjúklingur kvartaði ekki um vöðvamáttleysi en til mats á starfsemi öndunarvöðva var gert blásturspróf sem kom eðlilega út.

Kviðverkirnir fóru minnkandi en vegna áframhaldandi mikils slappleika og lystarleysis var ákveðið á fjórða degi að meðhöndla með hemarginati (Normosang ${ }^{\circledR}$ ), $3 \mathrm{mg} / \mathrm{kg} / \mathrm{dag}$ í æð í fjóra daga. Eftir pað fóru einkenni hratt batnandi og porfóbílínógen og úró-/kópróporfýrín í pvagi minnkuðu verulega. Sjúklingurinn útskrifaðist níu dögum eftir innlögn við mun 
Tafla I. Niðurstöður blóðrannsókna tilfellis.

\begin{tabular}{|c|c|c|c|}
\hline & Við innlögn & Dagur 3 & Dagur 5 \\
\hline Hvít blóðkorn (x10/L) [4,0-10,5] & 6,5 & - & - \\
\hline Hemóglóbín (g/L) [118-152] & $166^{*}$ & $173^{*}$ & 145 \\
\hline Blóđflögur (x10/L) [150-400] & $137^{\star}$ & - & - \\
\hline Natríum (mmól/L) [137-145] & $133^{*}$ & $119^{*}$ & $134^{*}$ \\
\hline Osmólalítet (mosm/kg) [280-300] & - & $246^{*}$ & - \\
\hline Kalíum (mmól/L) [3,5-5,0] & 3,7 & 3,5 & 3,5 \\
\hline Kreatínín (ㅆmól/L) [50-90] & 74 & 59 & 69 \\
\hline Lípasi (U/L) [25-300] & 271 & $1282^{*}$ & 186 \\
\hline Amýlasi (U/L) [25-120] & - & $209^{*}$ & 61 \\
\hline ASAT $(U / L)[<35]$ & $74^{*}$ & $60^{*}$ & - \\
\hline ALAT (U/L) [<45] & $112^{*}$ & $97^{*}$ & - \\
\hline $\mathrm{CRP}(\mathrm{mg} / \mathrm{L})[<3]$ & $<3$ & - & - \\
\hline $\begin{array}{l}\text { * Gildi utan við̌miðunarmarka } \\
\text { Einingar eru innan sviga og viðmiðuna }\end{array}$ & hornklofa & & \\
\hline
\end{tabular}

betri líðan. Útskriftarráðleggingar voru gefnar um kolvetnaríkt fæði, ásamt pví að forðast mataræðiskúra og stólpípumeðferðir.

Tveimur vikum síðar bárust endanlegar niðurstöður magnbundinna rannsókna á pvagi. Mikil hækkun fannst á delta-amínólevulinic sýru (ALA), 28,6 mmól/mól kreatínín $(<3,9)$, og porfóbilinógeni (PBG), 59,1 mmól/mól kreatínín $(<1,6)$. Einnig reyndist styrkur porfýrína hár, 325 $\mu$ mól/mól kreatínín $(<25)$, par af $82 \%$ úroporfýrín $(<20 \%)$. Niðurstöðurnar voru taldar samrýmast bráđu kasti slitróttar bráđaporfýríu (AIP). Pví miður reyndist ekki mögulegt að staðfesta greiningu með erfðarannsókn í pessu tilfelli.

Tafla II. Einkenni bráđakasts i AIP., 24-

\begin{tabular}{ll}
\hline \multicolumn{2}{l}{ Tiðni meðal AIP sjúklinga } \\
\hline Taugakvillar í sjálfvirka taugakerfinu & \\
\hline Kviðverkur & $85-95 \%$ \\
\hline Ógleði, uppköst & $43-88 \%$ \\
\hline Hægðatregða & $48-84 \%$ \\
\hline Hraður hjartsláttur & $64-85 \%$ \\
\hline Háprýstingur & $36-55 \%$ \\
\hline Útlægir taugakvillar & \\
\hline Verkir í útlimum, baki, brjóstkassa, hálsi og höfði & $50-70 \%$ \\
\hline Lömun, oftast í nærægum vöðvum & $42-68 \%$ \\
\hline Öndunarlömun & $9-20 \%$ \\
\hline Skyntruflanir & \\
\hline Pvagtregða & \\
\hline Miðlægir taugakvillar & $40-58 \%$ \\
\hline Óróleiki, svefntruflanir, rugl, ofskynjanir, punglyndi, kviói \\
\hline Flogakast & $10-20 \%$ \\
\hline Lækkun á natríumstyrk í plasma & \\
\hline *AlP - acute intermittent porphyria, & \\
\hline
\end{tabular}

\section{Umræða}

Meingerð

Porfýríur eru efnaskiptasjúkdómar orsakaðir af ensímgöllum í myndunarferli hems. Um 80\% af hemmyndun í líkamanum verður í tengslum við myndun blóðrauða í forstigum rauðra blóðkorna í beinmerg. Hem er einnig myndað í talsverðum mæli í lifur.

Myndun hems úr glýcíni og succinýl CoA er í átta skrefum og koma jafnmörg ensím við sögu (mynd 1). Fyrsta ensímið, 5-amínólevulínat synpasi (ALA synpasi), er hraðatakmarkandi. Í lifur hefur frítt hem og glúkósi hemjandi áhrif á ALA synpasa en fjölmargir pættir hafa örvandi áhrif. Í forstigum rauðra blóðkorna er tjáð annað gen fyrir ALA synpasa með stýringu tengdri járnflutningi og hemmyndun. Við myndun hems verða til nokkur milliefni. Par á meðal eru delta-amínólevulinat (ALA) og porfóbilinógen (PBG). Pessi milliefni eru undir eðlilegum kringumstæðum í litlu magni í líkamanum og hafa ekkert pekkt hlutverk umfram hemmyndun. Pegar ensímgalli er til staðar í myndunarferli hems, líkt og hjá sjúklingum með porfýríu, geta pessi milliefni safnast upp og haft eituráhrif. ${ }^{1}$

Porfýríur eru flokkaðar á tvo vegu, eftir pví hvort áđurnefnd milliefni safnast upp í lifur eða í forstigum rauðra blóðkorna og eftir klínískri mynd í bráđar porfýríur og húðporfýríur. Til eru fimm gerðir af porfýríum par sem milliefni safnast upp í lifur og eru fjórar peirra bráðar, pað er slitrótt bráðaporfýría (e. acute intermittent porphyria, AIP), arfgeng saurporfýría (e. hereditary coproporphyria, HPC), mislit porfýría (e. variegate porphyria, VP) og ALA dehydratasa porfýría (ADP). Pessar gerðir koma allar fram á fullorðinsaldri með bráðum köstum og hækkun á ALA og/eða PBG. Fimmta lifrarporfýrían er húðporfýría (e. porphyria cutanea tarda) og kemur fram sem margvíslegar húðbreytingar vegna ljósnæmis. Porfýríur sem verða vegna uppsöfnunar milliefna í forstigum rauðra blóðkorna eru meðfæddar porfýríur (congenital erythropoietic porphyria, CEP, og erythropoietic protoporfýría, EPP) og einkennast pær af uppsöfnun milliefna í beinmerg og rauðkornum og valda ofurnæmi húðar fyrir ljósi. ${ }^{1}$

AIP er algengasta porfýrían og stafar af galla í priðja ensíminu í myndunarferli hems, hýdroxýmetýlbílan synpasa (HMBS, einnig nefnt porfóbilinógen deamínasi). Genið sem tjáir HMBS er staðsett á litningi 11 og fjölmargar stökkbreytingar eru pekktar í pví. Peir sem hafa stökkbreytingu í HMBS geni hafa um pað bil helming af eðlilegri ensímvirkni. Mismunandi stökkbreytingar hafa mismunandi sýnd (e. pene- 
trance), til dæmis er stökkbreytingin W198X til staðar hjá helmingi porfýríusjúklinga í Svípjóð en pessi stökkbreyting leiðir oftar til sjúkdómseinkenna en margar aðrar. ${ }^{2}$

AIP er alla jafna einkennalaus. Við aðstæður par sem hemmyndun eykst í lifur vegna aukinnar myndunar cýtókróm P450 ensíma er hraðatakmarkandi ensímið ALA synpasi örvað. Takmörkuð starfsgeta HMBS verður pá ófullnægjandi og milliefni safnast upp. Ekki er vitað með hvaða hætti milliefnin valda einkennum porfýríu en pau eru talin hafa eiturvirkni, pá sérstaklega ALA. Pættir sem vitað er til að geti örvað ALA synpasa eru til dæmis sterar, ýmis lyf, áfengi, reykingar, streita, tíðablæðingar, fasta, sýkingar og kolvetnasnautt fæði (mynd 1). ${ }^{2}$ Í umræddu tilfelli virðast lág kolvetnainntaka og álag vegna stólpípa hafa stuðlað að bráðu kasti.

\section{Faraldsfræði}

Ensímgallarnir sem valda porfýríum erfast flestir A litnings ríkjandi (e. autosomal dominant) en porfýríur eru pó sjaldgæfur sjúkdómur. Aðeins $10-15 \%$ arfbera eru talin fá einkenni. Genagallinn er pó pað algengur að í sjaldgæfum tilvikum fæðast arfhreinir einstaklingar sem fá einkenni á barnsaldri og hafa jafnan alvarlegri einkenni en arfblendnir einstaklingar svo sem alvarlegar taugaraskanir og vöðva- og beinagrindargalla. ${ }^{3}$

Hæstu tíðni AIP er að finna í Svípjóð par sem nær einn af hverjum 1000 einstaklingum ber stökkbreytt HMBS gen og nærri helmingur peirra hefur fengið porfýríukast. ${ }^{2}$ Höfundum er ekki kunnugt um rannsókn á algengi AIP á Íslandi en ljóst er að mjög fáir hafa greinst hérlendis. Meðalaldur kvenna við greiningu í Svípjóð er 28 ára en 35 ára hjá körlum. AIP er fimm sinnum algengari hjá konum en körlum og konur fá jafnframt fleiri, lengri og alvarlegri köst en karlar. ${ }^{2}$ Vegna pessa er talið að hormónabúskapur líkamans og par á meðal magn estrógens og/eða prógesteróns í líkamanum skipti máli.

\section{Einkenni og teikn}

Einkenni AIP geta komið frá mörgum líffærakerfum og eru misalvarleg en einkenni frá meltingarvegi eru mest áberandi (tafla II). Kviðverkir eru algengir og orsakast af ristilkrömpum eða jafnvel garnalömun með penslu á kvið og minnkuðum garnahljóðum. Ógleði, uppköst, niðurgangur og hægðatregða eru einnig algeng einkenni. Pessi einkenni frá meltingarvegi stuðla oft að minni fæðuinntöku sem aftur getur gert kastið alvarlegra.

Algeng einkenni frá öðrum líffærakerfum eru meðal annars pvagtregða, hraður hjartsláttur,

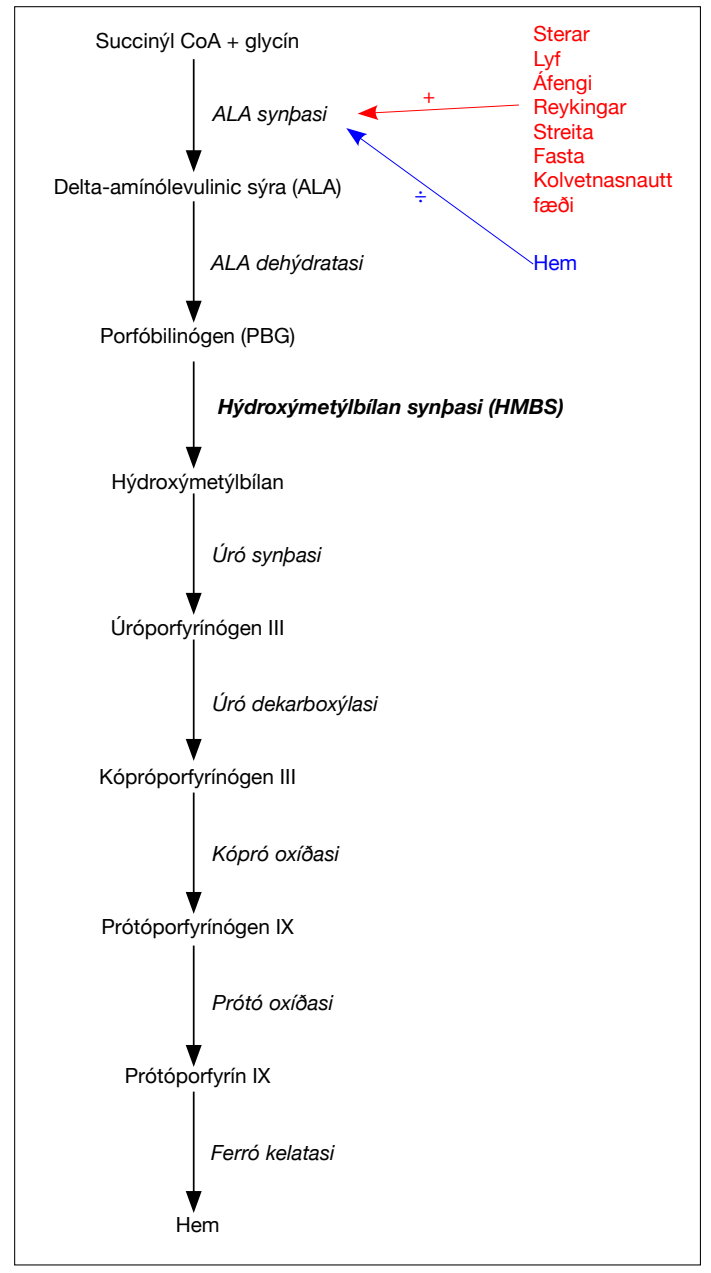

Mynd 1. Myndunarferli hems.

hækkaður blóðprýstingur, verkir, skyntap, vöðvaslappleiki og vöðvalamanir sem geta verið hratt versnandi. Í sumum tilfellum ná áhrifin til heilatauga og geta einnig valdið öndunarbilun vegna mænukylfulömunar. Pá eru pekkt geðræn einkenni og flogaköst. Skyndileg lækkun á natríumstyrk í plasma getur sést og er pá oft sambland heilkennis óviðeigandi seytingar $\mathrm{ADH}$ og mikils skorts á utanfrumuvökva (okkar tilfelli). ${ }^{1}$ Til eru lýsingar á nokkrum tilfellum bráorar brisbólgu í tengslum við porfýríukast en slíkt er sjaldgæft. ${ }^{4}$ Algengt er að sjúklingar hafi fleiri en eitt einkenni og í sænskri rannsókn voru preyta og geðræn einkenni algengust á eftir kviðverkjum. $^{2}$

Pegar einkenni og teikn eru ósértæk líkt og í okkar tilfelli og sjúklingur er af erlendu bergi brotinn parf að huga að ólíkum mismunagreiningum. Sem dæmi má nefna blýeitrun sem getur valdið kviðverkjum ásamt preytu, höfuðverk og lystarleysi. Sjúklingur frá AusturEvrópu gæti verið í aukinni hættu vegna mengunar frá iðnaði eða eldri tegunda málningar. Blý hindrar ýmis ensím, par á meðal ALA dehýdratasa og ferrókelatasa. Rannsóknir geta sýnt hækkun á ALA og kópróporfýríni í pvagi, 
blóðleysi og blettun rauðra blóðkorna með lútsæknum ögnum (e. basophilic stippling).

Greining

Góð einkennasaga, fjölskyldusaga og skoðun eru mikilvæg í greiningu porfýríu. Með mælingu á milliefnum hemmyndunar, ensímmælingum og leit að stökkbreytingum í meingenum má staðfesta greininguna.

Раð fer eftir porfýríu hvaða milliefni hemmyndunar eru aukin og hvar pau finnast, pað er hvar í myndunarferli hems er ensímgalli. Pær porfýríur sem verða vegna uppsöfnunar milliefna í forstigum rauðra blóðkorna (CEP og EPP) eru fyrst og fremst greindar með mælingu á milliefnum í rauðum blóðkornum. Pær porfýríur sem verða vegna uppsöfnunar milliefna í lifur, svo sem AIP, má aftur á móti greina með mælingu á milliefnum í pvagi og stundum einnig í saur. Sé pvag sjúklings með AIP látið standa nokkra stund dökknar pað í sumum tilfellum og verður rauðleitt vegna oxunar uppsafnaðra milliefna. Petta getur verið vísbending um greininguna. Staðfesting á AIP felst hins vegar í mælingu á ALA og PBG í pvagi eins og gert var í umræddu tilfelli. Auðvelt er að gera eigindleg útdráttarpróf fyrir PBG og úróporfýrín/cópróporfýrín. Pessi próf eru bó ekki 100\% sértæk og jákvæða niðurstöðu parf að staðfesta með magnbundnum prófum. Péttni ALA og PBG í pvagi er alltaf aukin hjá AIP sjúklingum með einkenni en hún getur einnig verið yfir eðlilegum viðmiðunarmörkum pegar peir eru einkennalausir. ${ }^{5}$ Styrkur porfýrína er oft aukinn í pvagi hjá sjúklingum með AIP vegna sjálfkrafa myndunar á úróporfýríni frá mikið hækkuðu PBG. Styrkur porfýrína í saur er yfirleitt eðlilegur hjá sjúklingum með AIP. ${ }^{6}$

Hjá sumum sjúklingum með AIP má staðfesta greiningu með pví að sýna fram á um 50\% lækkun á virkni ensímsins HMBS í rauðum blóðkornum. ${ }^{1}$ Sumir sjúklingar hafa hins vegar eðlilega virkni î rauðum blóðkornum pví peir hafa stökkbreytingu í peim hluta $H M B S$ gensins sem eingöngu er notaður við myndun lifrarísóforms ensímsins. Pessu til viðbótar má staðfesta greiningu AIP með pví að leita að stökkbreytingum í HMBS geninu. Petta próf má einnig nota í erfðaráđgjöf og skimun meðal fjölskyldumeðlima.

\section{Meðferð}

Brátt porfýríukast getur verið lífshættulegt og krefst tafarlausrar meðferðar til að fyrirbyggja alvarlega fylgikvilla. Afar mikilvægt er að stöðva tafarlaust gjöf peirra lyfja sem pekkt er að geta valdið bráđri versnun á porfýríu með pví að auka myndun milliefna. Par sem pekking á áhrifum lyfja á sjúkdóminn er takmörkuð skyldi fara varlega í gjöf allra lyfja. Listi yfir lyf sem eru talin örugg er aðgengilegur á netinu (til dæmis á www. porphyria-europe.com).

Meðferð bráđs porfýríukasts má skipta í sértæka meðferð sem stuðlar að pví að draga úr virkni ALA synpasa í lifur og í ósértækari einkennameðferð.

\section{Bæling ALA synpasa}

Virkni ALA synpasa er stýrt gegnum neikvæða afturverkun hems. Draga má úr offramleiðslu á ALA og par af leiðandi myndun á milliefnum með pví að leiðrétta undirliggjandi skort á hemi. Hægt er að gefa hemín sem er hem með klórsameind. Bestar virðast horfur vera ef hemín meðferð er hafin sem fyrst í bráđu porfýríukasti. ${ }^{1,7}$ Algengasta aukaverkun hemínmeðferðar er bláæðabólga.

Hemín er til í tvenns konar formum, hemarginat, sem er blanda hemíns og L-arginíns, og hematín (e. lyophyilized hydroxyheme). Hemarginat (Normosang ${ }^{\circledR}$ ) er oftast notað par sem pað hefur óveruleg eða engin bælandi áhrif á storkukerfið og líkur á bláæðabólgu eru litlar. Á meðgöngu ætti eingöngu að nota hem-arginat sé kastið alvarlegt par sem fáar rannsóknir liggja fyrir um mögulega skaðsemi pess. ${ }^{7,8}$ Ekki er hægt að gefa hemín um munn par sem pað er brotið niður af hem-oxygenasa við frásog í pörmum. Gefin eru 3-4 mg/kg/dag (pó aldrei meira en 250 $\mathrm{mg} /$ dag) hægt í fjóra daga í stærri útlæga eða miðlæga bláæð til að forðast bláæðabólgu. Yfirleitt kemur bati hratt fram ef gjöf hemíns hefst snemma í kasti, jafnvel á einum til tveimur dögum, og er pá sérstaklega átt við einkenni frá meltingarvegi. Meðferðin hefur ekki jafnmikil áhrif á einkenni frá taugakerfi. Gangi kastið ekki yfir á fjórum dögum má í undantekningartilfellum endurtaka meðferðina.

Gjöf kolvetna getur bælt virkni ALA synpasa og bætt næringarástand. Í mildum köstum par sem kviðverkir eru vægir og lömunareinkenni eru ekki til staðar geta kolvetni verið fullnægjandi meðferð. ${ }^{9}$ Í okkar tilfelli var ákveðið að hefja meðferð með kolvetnum par sem kastið var metið milt. Kolvetnagjöf má einnig nota samhliða hemínmeðferð. Mælt er með gjöf 5-10\% glúkósalausnar í æð og miðað við að gefa 300 grömm að lágmarki á sólarhring. ${ }^{1,9}$ Hafa ber í huga hættuna á lækkun natríumstyrks í plasma sem fylgt getur gjöf lausnarinnar í æð líkt og gerðist í okkar tilfelli. Reyna má kolvetnaríka fæðu um munn ef ógleði er ekki til staðar og ekki er grunur um garnalömun.

Hafi meðferð með gjöf kolvetna ekki dugað til og standi hemínmeðferð ekki til boða má reyna 
H2-viðtakahindrann címetidín. Címetidín hindrar virkni hem-oxídasa og minnkar pannig notkun á hemi. Pannig fæst fram minnkuð virkni ALA synpasa gegnum neikvæða afturverkun. ${ }^{10}$ Ekki eru pó til slembirannsóknir á virkni címetidíns í bráðu porfýríukasti og auk pess hefur lyfið verið tekið af markaði hérlendis.

Tilbúnar hliðstæður hems, svo sem tin prótóporfýrín, sem hindra virkni hem-oxygenasa á samkeppnisgrunni geta leitt til minnkaðs niðurbrots á hemi og aukins magns hems í lifur. Pessi meðferð er enn á tilraunastigi. ${ }^{11}$ Einnig hefur verið lýst bata hjá sjúklingi með alvarlega bráða porfýríu sem gekkst undir lifrarígræðslu en frekari rannsókna er pörf. ${ }^{12}$ Að auki er verið að rannsaka hvort leiðrétta megi ensímgallann hjá sjúklingum með porfýríu með genaflutningi. ${ }^{13}$

\section{Einkennameðferð}

Einkenni á borð við ógleði, uppköst, svefnleysi, kvíða og ofskynjanir má meðhöndla með fenóthíazínum, ${ }^{1}$ svo sem prómetazíni líkt og gert var í tilfellinu sem um ræðir. Við hægðatregðu má reyna neostigmín eða laktulósu og við kviðverk eða útlægum verkjum asetýlsalisílsýru, petidín eða ópíóía. Flog geta reynst erfið í meðhöndlun par sem flest flogaveikilyf geta gert porfýríukast verra. Benzódíazepín eru pó talin örugg ${ }^{1}$ sem og gabapentín. ${ }^{14}$ Íhuga ætti fyrirbyggjandi flogameðferð ef sjúklingur hefur lágan natríumstyrk í plasma. Vökvagjöf er mikilvæg vegna vökvaskorts og fylgja parf eftir elektrólýtum og kreatíníni í plasma. Gefa má saltvatn í æð en sem áður segir er gjöf sykurlausnar mikilvæg í sértækri meðferð og er pví fyrsta val ef gefa á vökva. Meðferð natríumlækkunar í plasma fylgir sömu ferlum og almennt er. Hraðtakt og háprýsting má meðhöndla með $\beta$-viðtakahindrum svo sem própranólóli eða labetalóli en fara skal varlega ef grunur er um vökvaskort. ${ }^{15}$ Í okkar tilfelli var sjúklingnum gefið labetalól með góðum árangri. Framkvæma ætti blásturspróf og fylgjast með öndunarrýmd til snemmgreiningar á mænukylfulömun. Komi fram öndunarslæving ætti að flytja sjúkling á hágæslueiningu par sem versnun getur orðið hröð. Fylgjast parf vel með einkennum frá taugakerfi, sérstaklega nærlægum vöðvastyrk, og vera á varðbergi gagnvart garnalömun, pani á pvagblöðru og geðeinkennum.

\section{Fylgikvillar}

Aukin hætta er á háprýstingi og afleiddri langvinnri nýrnabilun meðal porfýríusjúklinga og ætti pví að viðhafa árlegt eftirlit með blóðprýstingi og nýrnastarfsemi. ${ }^{16}$ Sjúklingar með bráða porfýríu eru í aukinni hættu á skorpulifur og lifrarfrumukrabbameini og mæla sumir með árlegum mælingum á $\alpha$-fetopróteini í sermi og ómskoðun á lifur meðal sjúklinga eldri en 50 ára. ${ }^{17}$ Punglyndi er algengara meðal sjúklinga með tíð köst eða krónísk einkenni. ${ }^{9}$ Komi taugaeinkenni fram geta pau gengið að fullu til baka með meðferð en pað getur einnig tekið marga mánuði fyrir alvarlega taugakvilla að ganga til baka pó að frampróun peirra stöðvist við meðferð.

\section{Horfur}

Fyrir 1970 var dánartíðni í bráđu porfýríukasti há. Með tilkomu betri greiningar og meðferðar ásamt greiningu arfbera og notkun forvarna hafa horfur batnað.9, 18 Í rannsókn meðal finnskra og rússneskra sjúklinga kom fram að tekist hefur að minnka hlutfall sjúklinga með einkenni úr 49\% í 17\%. Enn fremur skilaði góð fræðsla til sjúklinga pví að frekari köst voru fyrirbyggð meðal $60 \%$ sjúklinga með einkenni og 95\% sjúklinga án einkenna. ${ }^{19}$ Niðurstöður sænskra rannsókna eru á sama veg. ${ }^{20}$

\section{Forvarnir}

Mikilvægt er að fræða sjúklinga. Til að fyrirbyggja kast ætti að varast föstu eða mikla skerðingu á neyslu hitaeininga og forðast pau lyf og efni sem vitað er að geti kallað fram porfýríu. Forðast ætti áfengi og reykingar. ${ }^{2,21}$

Fyrirbyggjandi gjöf hemíns á eins til tveggja vikna fresti hefur stundum verið notuð ef um endurtekin köst er að ræða. ${ }^{22}$ Rannsóknir á gagnsemi eru pó takmarkaðar og hætta er á ofhleðslu járns. Hjá sumum konum framkallast kast í gulbúsfasa tíðahringsins og getur pá gjöf hliðstæðu gónadótrópín leysihormóns komið að gagni. ${ }^{23}$

Mælt er með erfðaráðgjöf og rannsókn hjá fyrstu gráðu ættingjum sjúklinga með porfýríu. Pannig má finna einkennalausa arfbera og fyrirbyggja bráð köst með fræðslu og forvörnum. ${ }^{2}$

\section{Lokaorð}

Slitrótt bráðaporfýría er efnaskiptasjúkdómur sem getur valdið bráðum og jafnvel hratt versnandi og lífshættulegum veikindum. Sjúkdómurinn er ekki algengur hérlendis og einkenni eru oft ósértæk og er pví mikilvægt að hafa aðrar mismunagreiningar í huga ef sjúklingar eru af erlendu bergi brotnir. Sjúklingurinn sem um ræðir vissi greininguna en vegna tungumálaörðugleika kom pað ekki fram við sögutöku og konan var í tvígang send heim án fullnægjandi rannsókna sem leitt hefðu til greiningar. Раð er von okkar að pessi grein verði 
til pess að auka vitneskju um porfýríur og bæta greiningu peirra.

\section{Heimildir}

1. Desnick RJ, Kenneth H.A. The Porphyrias. In: Fauci AS Kasper DL, Longo DL, et al, editors. Harrison's Principles of Internal Medicine. 17th ed. McGraw, 2008: 352-76.

2. Bylesjö I, Wikberg A, Andersson C. Clinical aspects of acute intermittent porphyria in northern Sweden: a populationbased study. Scand J Clin Lab Invest 2009; 69: 612-8.

3. Badminton MN, Elder GH. Molecular mechanisms of dominant expression in porphyria. J Inherit Metab Dis 2005; 28: 277-86.

4. Shiraki K, Takase K, Tameda Y, Kosaka Y. Acute pancreatitis associated with acute intermittent porphyria. Nippon Rinsho 1995; 53: 1479-83.

5. Aarsand AK, Petersen PH, Sandberg S. Estimation and application of biological variation of urinary deltaaminolevulinic acid and porphobilinogen in healthy individuals and in patients with acute intermittent porphyria. Clin Chem 2006; 52: 650-6.

6. Thadani H, Deacon A, Peters T. Diagnosis and management of porphyria. BMJ 2000; 320: 1647-51.

7. Mustajoki P, Nordmann Y. Early administration of heme arginate for acute porphyric attacks. Arch Intern Med 1993, 153: 2004-8

8. www.fass.se Apríl 2009.

9. Anderson KE, Bloomer JR, Bonkovsky $\mathrm{HL}$, et al Recommendations for the diagnosis and treatment of the acute porphyrias. Ann Intern Med 2005; 142: 439-50.

10. Cherem JH, Malagon J, Nellen H. Cimetidine and acute intermittent porphyria. Ann Intern Med 2005; 143: 694-5.

11. Dover SB, Moore MR, Fitzsimmons EJ, Graham A, McColl KE. Tin protoporphyrin prolongs the biochemical remission produced by heme arginate in acute hepatic porphyria. Gastroenterology 1993; 105: 500-6.
12. Soonawalla $\mathrm{ZF}$, Orug $\mathrm{T}$, Badminton $\mathrm{MN}$, et al. Liver transplantation as a cure for acute intermittent porphyria. Lancet 2004; 363: 705-6.

13. Johansson A, Moller C, Harper P. Correction of the biochemical defect in porphobilinogen deaminase deficient cells by non-viral gene delivery. Mol Cell Biochem 2003; 250: 65-71.

14. Tatum WOt, Zachariah SB. Gabapentin treatment of seizures in acute intermittent porphyria. Neurology 1995; 45: 1216-7.

15. Menawat AS, Panwar RB, Kochar DK, Joshi CK. Propranolol in acute intermittent porphyria. Postgrad Med J 1979; 55: 546-

16. Andersson C, Lithner F. Hypertension and renal disease in patients with acute intermittent porphyria. J Intern Med 1994; 236: 169-75.

17. Andersson C, Bjersing L, Lithner F. The epidemiology of hepatocellular carcinoma in patients with acute intermittent porphyria. J Intern Med 1996; 240: 195-201.

18. Jeans JB, Savik K, Gross CR, et al. Mortality in patients with acute intermittent porphyria requiring hospitalization: a United States case series. Am J Med Genet 1996; 65: 269-73.

19. von und zu Fraunberg M, Pischik E, Udd L, Kauppinen R. Clinical and biochemical characteristics and genotypephenotype correlation in 143 Finnish and Russian patients with acute intermittent porphyria. Medicine (Baltimore) 2005; 84: 35-47

20. Thunell S, Floderus Y, Henrichson A, Harper P. Porphyria in Sweden. Physiol Res 2006; 55: S109-18.

21. McColl KE, Thompson GG, Moore MR, Goldberg A. Acute ethanol ingestion and haem biosynthesis in healthy subjects. Eur J Clin Invest 1980; 10: 107-12.

22. Anderson KE, Collins S. Open-label study of hemin for acute porphyria: clinical practice implications. Am J Med 2006; 119: 801; e19-24

23. Anderson KE, Spitz IM, Bardin CW, Kappas A. A gonadotropin releasing hormone analogue prevents cyclical attacks of porphyria. Arch Intern Med 1990; 150: 1469-74.

24. Bloomer JR, McGuire BM. Intermittent unexplained abdominal pain: is it porphyria? Clin Gastroenterol Hepatol 2007; 5: $1255-8$

\section{Acute abdominal pain caused by acute intermittent porphyria - case report and review of the literature}

We describe a case of acute intermittent porphyria in a woman who presented repeatedly with abdominal pain. Porphyrias are caused by decreased enzyme activity in the heme biosynthetic pathway leading to overproduction of heme precursors if demand increases. This can cause symptoms such as abdominal pain, nausea and vomiting, constipation, tachycardia and hypertension. Treatment includes removal of causative factors, administration of carbohydrates or hemin to reduce the production of heme precursors as well as symptomatic treatment.

Birgisdóttir BT, Arnardottir S, Asgeirsson H, Jonsson JJ, Vidarsson B.

Acute abdominal pain caused by acute intermittent porphyria - case report and review of the

literature. Icel Med J 2010; 96; 415-20.

Key words: acute intermittent porphyria, pathophysiology, epidemiology, treatment

Correspondence: Brynjar Viðarsson, brynvida@landspitali.is 